MONIKA SUlEJEWICZ-NOWICKA
Biblioteka Uniwersytetu Łódzkiego

\title{
ANDRZEJ KEMPA JAKO BADACZ BIOGRAFII LUDZI KSIĄŻKI
}

Andrzej Kempa (1936-2009) to związany z Łodzią czołowy bibliotekarz, bibliograf i bibliofil. W latach 1974-1980 pełnił funkcję zastępcy dyrektora Biblioteki Głównej Akademii Medycznej w Łodzi. Od 1980 do 1996 roku był wicedyrektorem Miejskiej Biblioteki Publicznej im. L. Waryńskiego w Łodzi, następnie Wojewódzkiej i Miejskiej Biblioteki Publicznej im. Marszałka J. Piłsudskiego, obecnie Wojewódzkiej Biblioteki Publicznej im. Marszałka J. Piłsudskiego. Udzielał się społecznie. Był współzałożycielem, członkiem Zarządu (1969-1970) i sekretarzem (1971-1972) Łódzkiego Towarzystwa Przyjaciół Książki. Czynnie działał w Stowarzyszeniu Bibliotekarzy Polskich (był członkiem Zarządu Okręgu w Łodzi i Zarządu Głównego, wiceprzewodniczącym i przewodniczącym Okręgu) ${ }^{1}$. Autor licznych prac

${ }^{1}$ Andrzejowi Kempie poświęcono liczne prace: Bibliografia publikacji pracowników Akademii Medycznej w Łodzi za lata 1971-1990, oprac. J. Piotrowska, R. Żmuda, Łódź 2000; P. Bierczyński, Mowa pogrzebowa nad grobem Pana Andrzeja Kempy, „Na Stronie” 2009, nr spec., listopad, s. 2; P. Cichocki, Zmarli dyrektorzy, kierownicy i pracownicy bibliotek medycznych (1950-2008), „Forum Bibliotek Medycznych” 2009, nr 1, s. 58 (z portr.); A. Tymińska, Kempa Vladislav Andržej (27.06.1936-01.10.2009) [w:] Samarskaja Oblastnaja Universalnaja Naučnaja Biblioteka. Enciklopedia, sost. Anatoli Z. Zaval'nyj, Samara 2009, s. 184, (z portr. I bibliogr.); P. Bierczyński, Andrzej Kempa (1936-2009), „Akapit” 2010, t. 5, s. 121-124 (z portr.); R. Żmuda, Mgr Władysław Andrzej Kempa (1936-2009), „Kronikarz” 2009/2010, R. 8, nr 14, s. 462-470 (z portr. i bibliogr.); E. Pawlicka, Władysław Andrzej Kempa (27.06.1936-01.10.2009), „Bibliotekarz” 2010, [nr] 1, s. 28-30 (z portr.); taż, Władysław Andrzej Kempa (1936-2009), „Poradnik Bibliotekarza” 2010, 
historycznych, literaturoznawczych, językoznawczych, bibliotekarskich, bibliologicznych, księgoznawczych, czasopiśmienniczych, prasoznawczych oraz z historii drukarstwa, księgarstwa i ruchu wydawniczego, a także o tematyce regionalnej. Wśród jego publikacji pojawiają się prace prezentujące sylwetki antykwariuszy, księgarzy, drukarzy, introligatorów, nakładców, bibliotekarzy, bibliofilów, bibliografów, pisarzy, dziennikarzy. Biografie te zamieszczał w Encyklopedii wiedzy o książe, Polskim słowniku biograficznym i Słowniku pracowników książki polskiej oraz na łamach prasy łódzkiej i ogólnopolskiej, w tym specjalistycznej, popularnej, społeczno-kulturalnej i literackiej. Opracowywał cykl Pyłki - ciekawostki dotyczące książki, ludzi książki, wydarzeń związanych z biblioteką. Natomiast w innych cyklach: Zapiski bibliofila $z$ książek $i z$ życia wzięte, $Z$ różnych szuflad, Szkice trybunalskie, Biografie zasłużonych łodzian, $Z$ przedwczorajszej Łodzi i Łódzki słownik biograficzny prezentował biografie osób związanych z książką. W ostatnim z wymienionych cykli ukazującym się na łamach „Dziennika Łódzkiego" w latach 1995-1996 przybliżył łodzianom takie postaci jak: Antoni Remiszewski (nauczyciel i bibliofil), Horacy Safrin (poeta, satyryk, tłumacz), Juliusz Saloni (historyk literatury), Lazar Fuks (dziennikarz prasy żydowskiej), Marian Piechal (poeta, eseista, tłumacz), Oskar Flatt (dziennikarz, autor pierwszego opisu Łodzi), Przecław Smolik (literat), Roman Kaczmarek (dyrektor WiMBP im. J. Piłsudskiego w latach 1963-1980), Stanisław Książek (aktor, dziennikarz, właściciel drukarni), Stanisław Rachalewski (dziennikarz, sekretarz redakcji „Kuriera Łódzkiego”), Stefan Michał Gorski (publicysta, redaktor, wydawca) i Helena Duninówna (pisarka związana z Łodzią od 1945 roku).

W drukowanych wydawnictwach zwartych o charakterze encyklopedycznym i syntetycznym znalazły się opracowane przez Andrzeja Kempę hasła biograficzne pracowników książki, a więc księgarzy, nakładców, antykwariuszy (także łódzkich), drukarzy, introligatorów, bibliofilów, bibliografów i bibliotekarzy.

[nr] 1, s. 44-46 (z portr.); taż, Nasz bibliografista Andrzej Kempa (1936-2009), „Kronika Miasta Łodzi” 2010, [z.] 2, s. 203-205 (z portr.); taż Kempa Władysław Andrzej (27 VI 1936- 1 X 2009), w: Słownik pracowników książki polskiej. Suplement 3, pod red. H. Tadeusiewicz, Warszawa 2010, s. 131-132 (z bibliogr.); A. Chlebna, J. Dominikowska, J. Kantyka, Andrzej Kempa (19362009) - bibliotekarz, bibliofil, regionalista. Bibliografia, red. J. Kantyka, Łódź 2001 (tu: B. Czajka, Przedmowa, s. V-VI; P. Bierczyński, Z biogramu Andrzeja Kempy, s. VII-XIII); A. Strumiłło, Mgr Władysław Andrzej Kempa (1936-2009), „Forum Bibliotek Medycznych” 2012, R. 5, nr 2 (w druku); Andrzej Kempa (1936-2009). Spotkanie wspomnieniowe w 75. rocznice urodzin, Łódź 2011 (DVD). Wskazane prace podaje się za: R. Żmuda, Mgr Andrzej Kempa..., s. 470. 
W Encyklopedii wiedzy o książce pod redakcją Aleksandra Bierkenmajera, Bronisława Kocowskiego i Jana Trzynadlowskiego wydanej nakładem Zakładu Narodowego im. Ossolińskich w 1971 roku, łódzki badacz zaprezentował sylwetki dwóch postaci. Najpierw lwowskiego księgarza i nakładcy Jana Milikowskiego (1781-1866), właściciela sieci Księgarnia Narodowa i Zagraniczna, Handel Muzyczny i Umniczy Jana Milikowskiego we Lwowie, Stanisławowie i Tarnowie ${ }^{2}$. Następnie lwowskiego introligatora Zakładu Narodowego im. Ossolińskich we Lwowie, autora podręcznika z zakresu tej dziedziny wiedzy (Introligatorstwo. Z krótkim zarysem historii zdobnictwa opraw, Kraków 1948), bibliofila i bibliografa twórczości Adama Mickiewicza, twórcy kolekcji mickiewiczianów stanowiącej podstawę księgozbioru Muzeum Mickiewicza w Warszawie - Aleksandra Semkowicza $(1885-1954)^{3}$.

Kempa opracowywał również hasła do Słownika pracowników książki polskiej wydawanego w latach 1962-2010 z inicjatywy Adama Łysakowskiego (najpierw pod tytułem Słownik biograficzny pracowników książki polskiej), kontynuowanej w latach 1972-1986 przez Irenę Treichel, a od roku 2000 przez Hannę Tadeusiewicz . W sumie przygotował dziewięć biogramów, najwięcej (siedem) do wydania z roku 1972. W tym też tomie głównym zaprezentował sylwetki, osiemnasto-, dziewiętnasto- i dwudziestowiecznych postaci związanych z książką, sposobem jej wytwarzania, kolportowania i udostępniania. Przedstawił w nim: związanego z Krakowem i Warszawą księgarza i drukarza Józefa Bergera (1819-1884) ${ }^{5}$, lwowskich antykwariuszy i nakładców braci Bodeków (Hersza i Leona o nieznanych datach życia i śmierci) ${ }^{6}$, księgarza i działacza społecznego Ferdynanda Marka Heidenreicha (1868-1921) współwłaściciela Księgarni Polskiej w Petersburgu ${ }^{7}$, po raz drugi lwowskiego księgarza i nakładcy Jana Milikowskiego ${ }^{8}$, warszawskich antykwariuszy prowadzących rodzinny interes ojca - Gecla Salzsteina (Saltzstein, Zalcstein, Zalcsztajn 1773-1841) i jego dwóch synów: starszego - Jona Bera (założyciela Antykwarni Polskiej pf. B.J. Salztein) i młodszego - Lejby

${ }^{2}$ A. Kempa, Jan Milikowski [w:] Encyklopedia wiedzy o książce, pod red. A. Birkenmajera, B. Kocowskiego i J. Trzynadlowskiego, Warszawa [i in.] 1971, szp. 1542.

3 Tenże, Semkowicz Aleksander [w:] Encyklopedia..., szp. 2145.

${ }^{4}$ Zob. tenże, Łodzianie w stużbie książki, „Kronika Miasta Łodzi” 2001, z. 2, s. 84-87.

5 Tenże, Berger Józef [w:] Słownik pracowników książki polskiej, pod red. I. Treichel, Warszawa-Łódź 1972, s. 57-58.

${ }^{6}$ Tenże, Bodek Hersz; Bodek Leon [w:] Słownik..., s. 75-76.

7 Tenże, Heindereich Ferdynand Marek [w:] Słownik..., s. 323.

8 Tenże, Milikowski Jan [w:] Słownik..., s. 594-595. 
(antykwariusza i wydawcy) ${ }^{9}$, po raz drugi lwowskiego introligatora Aleksandra Semkowicza (1885-1954) ${ }^{10}$ oraz warszawskiego antykwariusza i historyka sztuki Hieronima Wildera (1876-1941), kierownika działu grafiki i rycin w Bibliotece Krasińskich w Warszawie i właściciela antykwariatu naukowego pf. Antykwariat Polski w Warszawie, Hieronima Wilder i Sp. ${ }^{11}$. W Suplemencie II z 2000 roku zamieścił biografię łódzkiego antykwariusza i zbieracza książek Henryka Maszewskiego (1910-1992), właściciela antykwariatu z wypożyczalnią książek pf. Księgarni-Czytelni „Słowo” mieszczącej się najpierw przy ulicy Piotrkowskiej 60, a następnie przeniesionej w 1949 roku na pasaż przy tej samej ulicy pod numerem 112 (obecnie al. L. Schillera) ${ }^{12}$. Z kolei w Suplemencie III (Łódź 2010) omówił dzieje łódzkiej bibliotekarki Iwony Książek (1944-2008), kierowniczki Działu Zbiorów Specjalnych w Miejskiej Bibliotece Publicznej im. L. Waryńskiego w latach 1975-199013.

W Polskim słowniku biograficznym opublikował zaś biogramy dwóch postaci. Po raz trzeci Jana Milikowskiego, tym razem wspólnie z Marianem Tyrowiczem, poszerzając dane o nieudany zakup od Adama Mickiewicza pierwodruku Pana Tadeusza, o kontakty z zagranicznymi firmami księgarskimi, współpracę z bibliotekami uniwersyteckimi i najważniejsze pozycje nakładowe. Autor biografii Milikowskiego omówił również jego dokonania $\mathrm{w}$ dziedzinie księgoznawstwa, albowiem był on jednym $\mathrm{z}$ organizatorów pierwszego zjazdu księgarzy i w tej dziedzinie wykształcił wielu specjalistów: Władysława Schmidta, Gustawa Seyfartha, Jana i Pawła Jeleniów ${ }^{14}$; po raz drugi przypomniał postać Gecla Salzsteina ${ }^{15}$.

Andrzej Kempa, zajmując się biografią ludzi książki i miłośników słowa pisanego, $\mathrm{w}$ równym stopniu skupiał się na czytelniku. Zależało mu niewątpliwie na dotarciu do szerszego grona odbiorców, dlatego też swoje prace o charakterze naukowym i popularnonaukowym zamieszczał w prasie łódzkiej i ogólnopolskiej.

9 Badacz szeroko omówił dzieje Gecla Salzsteina, wspominając o firmach jego synów w pracy Salzstein Gecel; Salzstein Jona Ber, Salzstein Lejba [w:] Słownik..., s. 784-785.

10 Tenże, Semkowicz Aleksander, Stownik..., s. 807-808.

11 Tenże, Wilder Hieronim [w:] Słownik..., s. 959.

12 Tenże, Maszewski Henryk [w:] Słownik pracowników książki polskiej. Suplement II, pod red. H. Tadeusiewicz z udziałem B. Karkowskiego, Łódź 2000, s. 105-106.

${ }_{13}$ Tenże, Książek Iwona [w:] Słownik pracowników książki polskiej. Suplement III, pod red. H. Tadeusiewicz, Warszawa 2010, s. 158-159.

${ }_{14}$ Tenże, M. Tyrowicz, Milikowski Jan [w:] Polski słownik biograficzny, t. 21, red. E. Rostworowski, Wrocław 1976, s. 219-220.

15 Tenże, Salzstein (Saltzstein, Salcsztajn, Zastein, Zalcsztajn) Gecel [w:] Polski słownik biograficzny, t. 36, red. H. Markiewicz, Wrocław 1992-1993, s. 396-397. 
Wiele uwagi poświęcał ludziom pióra, a więc zarówno dziennikarzom, jak i pisarzom. Przypominał czytelnikom sylwetki łódzkich dziennikarzy, m.in. Jana Kazimierza Wojtyńskiego (ur. 1899; data śmierci nieznana), korektora, sekretarza, a następnie redaktora „Kuriera Łódzkiego”. Kempa określił go "encyklopedią wiedzy o książce”, albowiem był znawcą regionu łódzkiego. Publikował anonimowo w "Republice”, a także w „Dzienniku Łódzkim”, „Kurierze Wielkopolskim” i „Musze”. Prowadził rubrykę Z dziejów Łodzi"

Podejmując badania nad biografią dziennikarzy, Kempa niejednokrotnie spotykał się z brakiem materiałów źródłowych. Z takim też problemem badawczym zetknął się, redagując Sylwetki łódzkich dziennikarzy i publicystów. Nie miał bowiem materiałów do życiorysu sekretarza redakcji „Kuriera Łódzkiego" i autora książek o tematyce łódzkiej Stanisława Rachalewskiego (1900-1945). W różny sposób zdobyte informacje biograficzne opublikował na łamach „Głosu Porannego" ${ }^{17}$.

Z łódzkich dziennikarzy zainteresowaniem biografisty cieszył się również publicysta, redaktor i wydawca Stefan Michał Gorski (1882-1940), który początkowo pod pseudonimem Michał Nałęcz, pisywał do: „Rozwoju”, „Gońca Łódzkiego”, „Ech Płockich i Łomżyńskich”, „Kuriera Sosnowieckiego”, warszawskiego „Kuriera Codziennego” i warszawskiego „Tygodnika Ilustrowanego" 18 .

Najwięcej miejsca w badaniach Kempa poświęcił dziennikarzom pochodzenia żydowskiego, którzy byli związani z Łodzią. Dwukrotnie prezentował więc czytelnikom postać Lazara Fuksa (1892-1935), współzałożyciela i redaktora „Najer Fołksbłat”, kierownika literackiego „Dos Naje Wort”, korespondenta „Łodzier Morgnbłat” i „Fołksbłat”19.

$\mathrm{Na}$ łamach „Kroniki Miasta Łodzi” przypomniał tych zamordowanych w czasie II wojny światowej, wymienił więc takie postaci jak: Henryk Herszel Passierman („Express Wieczorny”, redaktor depeszowy „Republiki”), Abram Alfred Grünfeld („Republika”), Szymon Glück pseud. Stefan Brylski („Republika”), Antoni Weiss („Republika”, „Express Ilustrowany”), Edward (Eliasz) From pseud. Andrzej Nullus („Republika”). Wspomniał również o tych, którzy byli zamknięci w łódzkim getcie. Zatem przypomniał takie osobistości jak: Eli Baruchin (poeta, krytyk, dziennikarz „Republiki”

\footnotetext{
16 Tenże, Wart przypomnienia, „Odgłosy” 1991, nr 20, s. 10.

17 Tenże, Rachalewski, „Głos Poranny” 1993, nr 300, s. 12; zob. też: tenże, Stanisław Rachalewski, „Dziennik Łódzki” 1995, nr 68, s. 12.

18 Tenże, Stefan Michał Gorski, „Dziennik Łódzki” 1995, nr 125, s. 16.

19 Tenże, Lazar Fuks (1892-1935), „Dziennik Łódzki” 1995, nr 86, s. 12; zob. też: Tenże, Redaktor Fuks i inni, „Słowo Żydowskie” 1992, nr 16/17, s. 27.
} 
i „Expressu Ilustrowanego”, redaktor „Illustrirter Pojliszer Menczester”), Jakub (Jakow) Obarzanek (autor komedii i dziennikarz „Fołksbłat”, „Najer Fołksbłat”, „Lodzier Togbłat”), kontrowersyjny Abraham Gancwajch (wydawca tygodnika rzekomo antyhitlerowskiego „Wolność”), Irena Weiss (dziennikarka „Expressu Ilustrowanego”), Mieczysław Kołtoński (redaktor „Zwierciadła Dziesięciu Muz” i „Głosu Kupiectwa”), Eliasz Tabaksbalt (członek komitetu redakcyjnego dwutygodnika „Nasze Dzieci w Domu i w Szkole”), Hersz Unikowski (redaktor „Fołks-Sztyme”), Julian Stanisław Cukier-Cerski (dziennikarz „Republiki”), Josek (Josef) Zelkowicz, Abraham Szulem Kamieniecki. Przywołał sylwetki dziennikarzy zamkniętych w getcie wileńskim, wspominając o takich postaciach jak: Chaim Jankiel Brzustowski (redaktor „Najer Fołksbałt” i „Republiki”, współredaktor „Expressu Wieczornego Ilustrowanego") i Juda Lajb Horowicz (poeta i założyciel miesięcznika literacko-ortodoksyjnego „Bet Jaakow”). Nie zapomniał także o tych, którzy wybrali ucieczkę do Wilna i Lwowa, a których i tak wywieziono lub ewakuowano w głąb Rosji. Przypomniał więc o takich postaciach jak: Mojżesz (Mosze) Broderson („Łodzier Togbłat” i „Najer Fołksbałt”), Gustaw Wassercug („Republika”, współwłaściciel i udziałowiec „Głosu Porannego”), jego córka Dorota (Dora) („Republika”), Jan Urbach (współwydawca i dziennikarz "Głosu Porannego") i Stefan Szmul Gelbart (redaktor dwutygodnika teatralno-filmowego „Scena i Film”, członek redakcji „Głosu Porannego"). Opowiedział również o tych, którzy ocaleli: bracia Kałuszyner, Adam (pseud. Ochocki) i Ludwik występujący pod przybranym nazwiskiem Starski, Adam Szenberg-Górski, Eugeniusz Kronman, Natan Eck ${ }^{20}$.

Obok dziennikarzy i krytyków, Kempa badał również biografie pisarzy, w tym związanych z Łodzią. W popularnej prasie ogólnopolskiej biografista przybliżał w licznych artykułach rocznicowych znanych polskich twórców słowa. Z życiorysów ludzi pióra niejednokrotnie wydobywał ciekawostki.

Badacz odniósł się więc do podróży Ignacego Krasickiego (1735-1801), jakie odbył po ziemi łódzkiej. Opisał m.in. pobyt pisarza w rezydencji dostojników Kościoła w Skierniewicach i w zamku arcybiskupim w Uniejowie w $1795 \mathrm{roku}^{21}$.

Kempa omówił także sylwetkę mazowieckiego lirnika - Teofila Lenartowicza (1822-1893). Przypomniał wiele faktów z życia poety, jak chociażby mariaż i małżeństwo z malarką Zofią z Szymanowskich, siostrą żony Ada-

${ }^{20}$ Tenże, Zamach na polską inteligencję. Dziennikarze $w$ łódzkim getcie, „Kronika Miasta Łodzi” 2009, z. 2, s. 31-38.

21 Tenże, Książę poetów w Skierniewicach, „Wiadomości Skierniewickie” 1980, nr 7, s. 9. 
ma Mickiewicza, wykłady w bolońskiej auli na temat życia i twórczości Jana z Czarnolasu czy pobyt w podłódzkim Ozorkowie i pobliskiej wsi Wyrobki w dobrach szlachcica Stokowskiego. Scharakteryzował też jego twórczość literacką i rzeźbiarską 22 .

Łódzki badacz publikował również przyczynki do biografii ludzi książ$\mathrm{ki}$, niejednokrotnie sprostowując informacje biograficzne lub dotyczące twórczości. Tak było też w przypadku duchownego i poety Symoforiana Tomickiego (1817-1877) autora Kwiatów więzienia, w których opisał swoje więzienne przeżycia. W zakładzie w Berlinie znalazł się za zamieszczenie w znamiennym 1863 roku w redagowanej gazetce „Szkółka Niedzielna” tekstu propagandowego głoszącego hasła niepodległościowe. Wnikliwy badacz uściślił również informację o atrybucji rozprawy Przetor dla rozgmatwania plemion osiedzibiających Sarmacja i Germania starożytna (Poznań 1843)23, której autorem według Estreichera miał być rzeczony ksiądz. Biografista wskazał natomiast na Jana Bazylego Tomickiego, ojca Symoforiana.

Kempa w badaniach biograficznych zajmował się także postaciami znanymi, ale zapomnianymi. Przypomniał zatem ogólnopolskim czytelnikom „Tygodnika Polskiego” sylwetkę pisarki Jadwigi Łuszczewskiej (1834-1908) znanej jako Deotyma. Badacz przytoczył kilka faktów z życia tej poetki doby romantyzmu, a przede wszystkim z jej życia towarzyskiego, takie jak liczne spotkania środowiska w domowym zaciszu, towarzyszący im ceremoniał obwieszczania Deotymy królową i wygłaszania przez nią improwizacji na zaproponowane przez gości tematy. Omówił także fenomen jej popularności, przytaczając niepochlebne wypowiedzi krytyków literackich takich jak Lucjan Siemieński oraz kąśliwe i ironiczne w swej wymowie uwagi cenionych poetów takich jak Kajetan Koźmian i Adam Mickiewicz. Scharakteryzował również jej twórczośćc ${ }^{24}$.

Na łamach popularnej gazety łódzkiej o zasięgu ogólnopolskim „Odgłosy” Kempa poświęcił jeden artykuł postaci Józefa Ignacego Kraszewskiego (1812-1887) z okazji setnej rocznicy jego śmierci. Pokrótce omówił sylwetkę pisarza i charakterystykę jego twórczości, która przeżywała wówczas renesans, uznając go za pisarza wciąż żywego i chętnie czytanego. Ubolewał jednak nad brakiem pełnej bibliografii twórczości autora, pomimo ukazania się jej zarysu w 1966 roku$^{25}$.

\footnotetext{
22 Tenże, Czy to lirnik, „Odgłosy” 1983, nr 8, s. 9.

23 Tenże, Przygoda proboszcza z Konojadu, „Tygodnik Polski” 1983, nr 7, s. 13.

24 Tenże, Wieszczka Deotyma, „Tygodnik Polski” 1984, nr 32, s. 13.

25 Tenże, Fenomen Kraszewskiego (W setna rocznicę śmierci), „Odgłosy” 1987, nr 11, s. 9.
} 
Badania Kempy dotyczące życia ludzi pióra są niezwykle cenne, gdyż wielokrotnie weryfikował on informacje biograficzne. Tak było w przypadku dziewiętnastowiecznego autora ody Po zgonie wiekopomnej pamięci Aleksandra I, Cesarza Wszech Rossyi, Króla polski itd. itd. Ksawerego Flejczerowskiego. Jak badacz dowodził, na karcie tytułowej dzieła mylnie wydrukowano nazwisko twórcy ody jako Fleczerowski, co zostało później sprostowane na łamach „Kuriera Warszawskiego” z 10 kwietnia 1826 roku $^{26}$.

By wzbudzić u czytelników zainteresowanie literaturą, bibliolog zaprezentował na łamach „Bibliotekarza” sylwetkę nowelistki, powieściopisarki, publicystki, a przede wszystkim autorki poezji o książkach - Zuzanny Rabskiej (1882-1960). Autor nie tylko wskazał na kilka faktów biograficznych z życia pisarki, weryfikując również datę jej urodzenia, ale przede wszystkim skupił się na zaakcentowaniu jej zamiłowania do słowa pisanego, uważnej lektury, kolekcjonowania książek i ukształtowania jej osobowości przez dom rodzinny i znaczących gości jej rodziców - Aleksandra Kraushara i Jadwigi z Bersohnów, wśród których znaleźli się wybitni uczeni, ludzie pióra, warszawscy bibliofile. Kempa podkreślił, że Rabska była przede wszystkim poetką książki. Według jego badań ogłosiła łącznie kilkadziesiąt liryków i przekładów, a ich większość zamknęła w kunsztownej formie czternastowersowego sonetu, a więc tej formy artystycznego obrazowania, która najgodniej opiewa piękno słowa ${ }^{27}$.

Kempa dwukrotnie w „Odgłosach” w 1989 roku przedstawił sylwetkę przedwcześnie zmarłego duchownego, poety i dramatopisarza, związanego m.in. z Łodzią - Antoniego Szandlerowskiego (1878-1911). Najpierw w numerze 34 omówił jego oryginalną twórczość liryczną, którą ogłaszał na łamach „Rozwoju” (wiersze Z mojego ogrodu, Pieśni), cieszące się uznaniem wśród krytyków dramaty (Samson) i poematy dramatyczne (Maria $z$ Magdali, Triumf). Młody twórca duchowny uznany jednak został przez swoich zwierzchników za niepokornego, albowiem doszukali się w jego utworach znamion świadczących o naruszeniu godności kapłańskiej i apostazji oraz niezgodności z zasadami Kościoła. Natomiast za napisanie anonimowo wydanej broszury Elenchus cleri alias choleri saecularis ac irregularis Cosistorii Varsaviensis pro Anno Domini 1906 abo Ołtarzyk Złoty, gdzie znajdziesz sprosne żywoty braciej konsystorskiej został zesłany na służbę do Mąkolic koło Łodzi ${ }^{28}$. Następnie w numerze 37 Kempa zamieścił przyczynek do jego

\footnotetext{
${ }_{26}$ Tenże, Błąd w nazwisku, „Bibliotekarz” 1988, nr 4-5, s. 43.

27 Tenże, Zuzanna Rabska - poetka książki, „Bibliotekarz” 1988, nr 10-11, s. 56-59.

28 Tenże, Wikary od Świętego Krzyża, „Odgłosy” 1989, nr 34, s. 15.
} 
biografii i opisał historię jego romansu z Heleną Beatus (literacką Bożenną), która po jego tragicznej śmierci z powodu powikłań po różyczce, zajęła się wydaniem jego spuścizny literackiej oraz napisała powieść autobiograficzną zatytułowaną Zachód ${ }^{29}$. Do warszawskiej pary Abelarda i Heloizy powrócił w 2002 roku na łamach „Wędrownika” ${ }^{30}$.

Biografista na łamach „Odgłosów” przedstawił również postać Geoffrey’a Potockiego de Montalk (1903-1997), nowozelandzkiego poety, tłumacza literatury polskiej, potomka polskiej szlachty, który samozwańczo obwołał się królem Władysławem V. Kempa oparł omówione fakty z życia i twórczości Potockiego na istniejącej literaturze przedmiotu (R.T. Risk Why Potocki?) i własnych badaniach, bowiem dotarł do osób znających samozwańczego monarchę i do jego korespondencji ${ }^{31}$.

Łódzki badacz zainteresował się również życiorysem Ludwika Starzewicza, który zasłynął m.in. publikacją Antologii 120 poetów. Wiersze na obchody uroczystości wydaną pod pseudonimem Adam Goliński. Pozycja ta przysporzyła mu nie lada kłopotów. Autorzy włączonych do antologii tekstów domagali się bowiem honorarium. Skandal przybrał takie rozmiary, że potrzebne było wstawiennictwo samego Juliana Tuwima u urażonych twórców, o które poprosił ówczesny prezes Zarządu Oddziału Związku Literatów Polskich w Łodzi, Jan Nepomucen Miller ${ }^{32}$.

Na łamach „Głosu Porannego” Kempa przypomniał postać i twórczość Aleksandra Kraśniańskiego (1909-1929), poety i dziennikarza publikującego pod pseudonimem Pierrot ${ }^{33}$.

Biografista przywoływał także znanych twórców opiewających region łódzki. Omówił więc poemat Rzeki wielkie. Poema pomniki sławy narodowej opiewajace Kajetana Jaxy Marcinkowskiego (ok. 1788-1832) powstały podczas pobytu autora w Płocku. Marcnikowski, będąc obiektem kpin w środowisku literackim z powodu napisania poematu heroikomicznego Gorset, prawdopodobnie za protekcją Kajetana Koźmiana otrzymał w płockiej szkole posadę inspektora. Nadto Kempa przypomniał postać Marcinkowskiego i jego utwór, albowiem znalazł wypowiedź jednego z czytelników, iż „nie jest to ladaco"34.

29 Tenże, Czarna gołębica, „Odgłosy” 1989, nr 37, s. 15.

30 Tenże, Wikary i czarna gołębica, „Wędrownik” 2002, nr 4, s. 37-39.

${ }^{31}$ Tenże, Przygody Króla Jegomości, „Odgłosy” 1989, nr 32, s. 15.

32 Tenże, W atmosferze skandalu, „Odgłosy” 1991, nr 24, s. 11.

${ }_{33}$ Tenże, Pierrot, „Głos Poranny” 1994, nr 17, s. 12. Zob. też: tenże, Redaktor Fuks i inni, „Słowo Żydowskie” 1992, nr 16/17, s. 27.

${ }_{34}$ Tenże, Jaxa i jego płockie rymy, „Głos Poranny” 1994, nr 51, s. 12. 
Andrzej Kempa przybliżał czytelnikom również postaci znanych twórców słowa, odwołując się do nieznanych faktów z ich życia i ciekawostek. Tak też było w przypadku Juliana Tuwima (1894-1953). Badacz odniósł się do sporu wokół miejsca pierwszego zamieszkania poety przy Pasażu Szulca (obecnie al. 1 Maja) bądź przy ul. Widzewskiej 44 (obecnie ul. Kilińskiego 46), pozostawiając kwestię nierozstrzygniętą. Sam Tuwim przyznawał, że daty przeprowadzki z Widzewskiej na pasaż Szulca nie pamięta ${ }^{35}$. Omówił jego lata dzieciństwa i wczesnej młodości spędzone w Łodzi, zwracając uwagę na zamiłowanie do mowy wiązanej rodziców, a przede wszystkim matki - Adeli z Łapowskich. Wspomniał o szkolnej awersji poety do matematyki oraz o fascynacji chemią i naukami przyrodniczymi, a także o opuszczaniu co drugi dzień zajęć lekcyjnych. Biografista odnotował również fakt przeniesienia się rodziny Tuwimów w 1905 roku do Wrocławia z powodu nasilającego się w Łodzi antysemityzmu. Podkreślił też, że pierwsze wiersze poety powstały $\mathrm{w}$ Inowłodzu podczas wakacji. Wspomniał o jednym z pierwszych chronologicznie liryków zatytułowanym Sen z 1911 roku, a dedykowanym H.K. - Halinie Kon, którą Tuwim poznał w Tomaszowie. Przypomniał też debiut poetycki Tuwima na łamach „Kuriera Warszawskiego" z 6 stycznia 1913 roku. Biografista omówił również zażyłości, jakie łączyły Tuwima z Leopoldem Staffem, który to był jednym z pierwszych krytyków poety, albowiem dziewiętnastoletni wówczas Tuwim wysyłał mu odpis wierszy z prośbą o lekturę. Kempa nie pominął też informacji o zainteresowaniach bibliofilskich i kolekcjonerskich Tuwima. Poeta zakupił bowiem w warszawskim antykwariacie Klepfisza na ul. Elektoralnej szesnastowieczny traktat łacińskich o grzechach oprawiony w pergamin $\mathrm{z}$ epoki. Autor eseju biograficznego skupił się na pasji lingwistycznej, translatorskiej oraz teatrologicznej poety ${ }^{36}$.

Wśród twórców słowa w badaniach biograficznych Kempy miejsce znalazł również Marian Piechal (1905-1989), łódzki poeta, twórca grupy literackiej Meteor i czasopisma o tej samej nazwie, członek Kwadrygi, eseista i tłumacz, którego sylwetkę Kempa przedstawił w krótkim biogramie zamieszczonym na łamach „Dziennika Łódzkiego” w cyklu Łódzki słownik biograficzny ${ }^{37}$.

35 Tenże, Gdzie się właściwie urodzit Tuwim?, „Dziennik Łódzki” 1995, nr 270, s. 23.

${ }^{36}$ Tenże, Przedwiośnie literackie Juliana Tuwima: biografia i rzecz poetycka, „Miscellanea Łódzkie” 1994, nr 2, s. 5-13; tenże, „To, że stałem się poetą...”, „Tygiel Kultury” 2005, nr 4/6, s. 94-100.

37 Tenże, Marian Piechal, „Dziennik Łódzki” 1995, nr 131, s. 18. 
Kreśląc szkice biograficzne literatów związanych $\mathrm{z}$ Łodzią i regionem, Kempa poświęcił dwa teksty lekarzowi, literatowi i bibliofilowi Przecławowi Smolikowi (1877-1947) nazywanemu przez Janusza Dunina „mentorem dawnej Łodzi”. Pierwszy szkic dotyczy jego biografii, a drugi traktuje o jego łódzkich inicjatywach kulturalnych. Badacz wskazał więc jego najważniejsze zasługi na rzecz, jak to sam określał, „złego miasta”, tj.: powołanie Towarzystwa Bibliofilów (1927), przejęcie w darze księgozbioru trzech pokoleń rodziny krakowskiego publicysty Kazimierza Bartoszewicza (1928), powiększenie Miejskiej Biblioteki Publicznej mieszczącej się wówczas przy ul. A. Struga 14 (1929), utworzenie Muzeum Historii i Sztuki (1930), Miejskiego Muzeum Przyrodniczo-Pedagogicznego (1930) i Miejskiego Muzeum Etnograficznego (1931), pozyskanie dla Muzeum Historii i Sztuki kolekcji prac grupy „a.r.” (1932) ${ }^{38}$.

Jako dociekliwy badacz, Kempa słusznie zweryfikował informacje biograficzne o łódzkiej poetce o pseudonimie Maria Przedborska (ur. 1888; data śmierci nieznana), powtórzone przez Tadeusz Gicgiera w Opowieściach o dawnych poetach Łodzi (Łódź 1995) za Ziemowitem Skibińskim i Barbarą Stelmaszczyk-Świontek - autorami antologii Kwiaty łódzkie. Antologia poezji o Łodzi (Łódź 1982). Za sprawcę chaosu uznał Marka Czuku, który w felietonie literackim Poetki Łodzi ${ }^{39}$ wskazał na istnienie dwóch twórczyń o tym samym pseudonimie. Odrzucił też hipotezę Krzysztofa Tomasza Witczaka sformułowaną w pracy Uwagi o łódzkiej poetce Marii Przedborskiej o polskojęzycznej twórczości Miriam Ulinower kryjącej się pod pseudonimem Maria Przedborska ${ }^{40}$.

Oprócz badania biografii twórców słowa, Kempa zajmował się również życiorysem osób związanych z kolportowaniem, pozyskiwaniem, opracowaniem i udostępnianiem szerszemu gronu odbiorców książki. Mowa więc o bibliotekarzach, bibliofilach, drukarzach, księgarzach i wydawcach.

Swoją uwagę skupił na osiemnastowiecznym pionierze rynku księgarskiego dawnej Rzeczypospolitej Michale Gröllu (1722-1798). Omówił dzieje jego księgarni powstałej w 1759 roku w Warszawie. Wskazał na liczne przywileje i tytuły (servitor regius i commisarius reguis et auctionar), którymi obdarzył go król Stanisław August Poniatowski, a które pomogły mu w rozwoju firmy. Wydawca bowiem założył obok księgarni biuro, które pełniło

${ }_{38}$ Tenże, Przecław Smolik, „Dziennik Łódzki” 1995, nr 177, s. 12; tenże, Łódzkie inicjatywy kulturalne Przecława Smolika, „Kronika Miasta Łodzi” 1999, z. 1/2, s. 67-76.

${ }_{39}$ M. Czuku, Poetki Łodzi, „Kronika Miasta Łodzi” 2006, z. 3, s. 82-84.

40 A. Kempa, Odkryta tajemnica. Kim była Maria Przedborska?, „Kronika Miasta Łodzi” 2008, z. 3, s. 271-274. 
rolę ośrodka informacyjnego i pośrednictwa pracy oraz pierwszą publiczną wypożyczalnię książek. W latach 1775-1792 był najwybitniejszym wydawcą i księgarzem polskim, który jako jedyny dbał o różnorodność wydawniczą i szatę graficzną dzieł ${ }^{41}$.

Kempa przedstawił również sylwetkę znanego toruńskiego historyka i badacza dziejów polskiego księgarstwa, autora De typographiis earumque initiis et incrementis in Regno Poloniae et Magno Ducatu Luthuaniae cum variis observationibus rem et literariam et typographicam utriusque gentis eliqua ex parte illustrantibus (Gdańsk 1740) - Jana Daniela Hoffmanna (17011766). Badacz szeroko omówił wiekopomne dzieło Hoffamanna, przywołując opinie wybitnych znawców dziejów polskiego drukarstwa i księgarstwa, a mianowicie Joachima Lelewela i Jerzego Samuela Bandtkiego ${ }^{42}$.

Kempa zaprezentował także wileńskiego wydawcę i księgarza Teofila Glücksberga (1796-1876) z pierwszej połowy XIX wieku. Biografista skupił się przede wszystkim na odbiorze księgarza przez twórców słowa, m.in. Józefa Korzeniowskiego, który Glücksberga poznał jako nastoletniego chłopca pomagającego ojcu w prowadzeniu księgarnii. Wówczas pisarze zarzucali wydawcom brak właściwej oceny artystycznej dzieła oraz sprzedaż każdego z nich jako najwartościowsze, a więc i najdroższe. Dalej biografista omówił literacki portret wydawcy. Autor Kollokacji do sztuki zatytułowanej $\dot{Z} y d z i$ wprowadził postać księgarza Goldberga, który za przyjęcie do druku rękopisu nieznanego autora nie tylko pobrał honorarium, ale i kazał pisarzowi dopłacić „200 karbowanych”, twórcy zaś obiecując bezpłatne „20 egzemplarzy na welinowym papierze" 43 .

Ważne miejsce w badaniach Kempy zajmuje niewątpliwie galicyjski księgarz - Jan Milikowski, którego biografię zamieścił już we wcześniej tu omówionych wydawnictwach encyklopedycznych i syntetycznych. Po raz pierwszy jego sylwetkę zaprezentował jednak na łamach fachowej prasy ogólnopolskiej w 1961 roku, wzbogacając o dzieje lwowskiego rynku wydawniczego $\mathrm{w}$ pierwszej połowie XIX wieku oraz o ciekawe fakty z życia księgarza, który wykorzystując znajomości z właścicielami księgarń w Paryżu, Lipsku, Pradze i Wiedniu, wydawał i upowszechniał nielegalną literaturę emigracyjną z Księgami narodu i pielgrzymstwa polskiego (w języku polskim i niemieckim) czy Konradem Wallenrodem (w edycji paryskiej) Adama Mickiewicza na czele. $\mathrm{W}$ ten sposób omijał zakazy cenzuralne i obowiązujące

\footnotetext{
41 Tenże, O Michale Gröllu: księgarzu JKM-ci, „Głos Księgarza” 1956, nr 28, s. 2.

42 Tenże, Pierwszy historyk drukarstwa polskiego i jego dzieło, „Księgarz” 1959, nr 9-10, s. 14.

43 Tenże, Drugie spotkanie z Teofilem Glücksbergiem, „Księgarz” 1959, nr 9-10, s. 15, 18.
} 
przepisy, za co kilkakrotnie skazano go na areszt i karę grzywny. Ponadto Kempa wskazał na zasługi wydawnicze Milikowskiego, bowiem był on jednym z pierwszych wydawców, który właściwie ocenił i docenił wartość na rynku księgarskim utworów Mickiewicza. Lwowski księgarz wydał również dzieła Wincentego Pola, Antoniego Malczewskiego, Aleksandra Fredry, Klementyny z Tańskich Hoffmanowej ${ }^{44}$.

Andrzej Kempa jako wnikliwy badacz biografii ludzi książki, podniósł kwestię mało znanego faktu, jakim jest polskie pochodzenie wybitnego rosyjskiego księgarza i drukarza - Bolesława Maurycego Wolffa (1826-1883). Autor objaśnił relacje wydawcy z historykiem Janem Bartoszewiczem na podstawie ich wspólnej korespondencji. Celem było pokazanie losów książek z perspektywy edytora i księgarza, który w równym stopniu jak autor był narażony na niepowodzenie wydawnicze i związane z nim straty finansowe ${ }^{45}$.

Ponadto Kempa, omawiając biografie poszczególnych postaci związanych ze słowem, podejmował zagadnienia $\mathrm{z}$ innych dziedzin jak np. historia prasy. Na łamach „Spotkań z Zabytkami” przywołał sylwetkę Ksawerego Zubowskiego (1744-1808), autora projektu periodyku z 1786 roku „Kolekcyja starożytnych i tego czasowych osobliwości w kraju i za krajem znajdujących się naród polski interesujących", który nie powiódł się ze względu na brak środków finansowych i zaistniałe okoliczności (upadek Sejmu Czteroletniego i insurekcję kościuszkowską) ${ }^{46}$.

Badając zagadnienie historii prasy, Kempa zajął się także historią prasy regionu łódzkiego. Przybliżył czytelnikom sylwetkę wydawcy łódzkich periodyków, tj. „Kurier Łódzki Ilustrowany”, „Kurier Łódzki”, „Łódzkie Echo Wieczorne”, „Echo”, a mianowicie Jana Stypułkowskiego (1884-1939) ${ }^{47}$.

Badacz publikował także życiorysy znanych łódzkich bibliotekarzy. $\mathrm{Na}$ łamach „Bibliotekarza” w 1985 roku omówił sylwetkę archiwisty, bibliografa, pracownika naukowego i dydaktyka, działacza społecznego i politycznego oraz dyrektora Miejskiej Biblioteki Publicznej im. L. Waryńskiego w Łodzi - Romana Kaczmarka (1912-1985). Przypomniał istotne fakty z życia starszego kustosza dyplomowanego. Interesowała go edukacja, kariera zawodowa czy praca naukowo-dydaktyczna, zasługi na rzecz regionu łódzkiego, m.in. liczne prace biograficzne o działaczach politycznych i społecz-

\footnotetext{
${ }^{44}$ Tenże, Rewolucyjny księgarz galicyjski Jan Milikowski, „Księgarz” 1961, nr 15-16, s. 22-23.

${ }_{45}$ Tenże, Bolesław Maurycy Wolff w świetle nieznanej korespondencji, „Księgarz” 1980, nr 3, s. $48-51$.

46 Tenże, Prekursor „Spotkań z Zabytkami”, „Spotkania z Zabytkami” 1983, nr 3, s. 58-59.

47 Tenże, Jan Stypułkowski (1884-1939), „Dziennik Łódzki” 1995, nr 74, s. 12.
} 
nych oraz o pracownikach nauki i kultury zamieszczone w Polskim słowniku biograficznym, a także rozprawy naukowe dotyczące historii Łodzi i okolic publikowane w „Roczniku Oddziału Łódzkiego Polskiego Towarzystwa Historycznego”, „Dzienniku Zarządu Miejskiego Miasta Łodzi”, „Czasopiśmie Przyrodniczym”, „Wiadomościach Diecezjalnych Łódzkich”. Jako wybitny bibliograf i dyrektor miejskiej biblioteki publicznej wyodrębnił w jej strukturze Pracownię Regionalną, mając na względzie utworzenie z niej głównego ośrodka wiedzy o regionie ${ }^{48}$. Natomiast w „Odgłosach” zamieścił jego pożegnalne wspomnienie wraz z krótkim życiorysem ${ }^{49}$.

Kempa zaprezentował również postać Małgorzaty Basińskiej (19441988), bibliolożki i bibliografki zajmującej się przede wszystkim tworzeniem Bibliografii Łodzi i województwa łódzkiego, pracownicy Miejskiej Biblioteki Publicznej im. L. Waryńskiego w Łodzi ${ }^{50}$.

Biografista „Informatora Bibliotekarza i Księgarza na Rok 1988” przedstawił czytelnikom sylwetkę historyka papiernictwa, pracownicy naukowej PAN, bibliotekarki związanej z Instytutem Celulozowo-Papierniczym w Łodzi doc. dr hab. Jadwigi Siniarskiej-Czaplickiej (1913-1986). Omówił jej edukację i karierę naukową, podkreślając dokonania na rzecz biblioteki instytutu, która stała się potężnym ośrodkiem $\mathrm{z}$ jednym $\mathrm{z}$ najbogatszych zbiorów z filigranistyki i historii papiernictwa. Kempa wskazał również na dorobek piśmienniczy Siniarskiej obejmujący kilkadziesiąt artykułów z zakresu papiernictwa, bibliotekarstwa i informacji naukowej ${ }^{51}$.

W 1989 roku przedstawił wybitnego badacza życia i twórczości Kamila Cypriana Norwida i bibliografa, księgoznawcy i współwłaściciela warszawskiego antykwariatu „Biały Kruk” - Juliusza Wiktora Gomulickiego (1909-2006). Zaprezentował jego badania nad autorem Vade-mecum oraz wspomniał o umiłowaniu słowa zaszczepionym przez ojca - Wiktora Gomulickiego, powieściopisarza, publicysty i bibliofila. Kempa omówił także dzieje bogatej domowej biblioteczki Gomulickich. Skupił się na pasji bibliofilskiej tego wybitnego historyka literatury, wskazując na jego najcenniejsze pozycje pozyskane $\mathrm{w}$ drodze długotrwałych i żmudnych poszukiwań na antykwarycznych półkach i na jego pierwsze samodzielne zakupy doko-

\footnotetext{
48 Tenże, Roman Kaczmarek 1912-1985, „Bibliotekarz” 1985, nr 12, s. 22-24.

49 Tenże, Roman Kaczmarek, „Odgłosy” 1985, nr 23, s. 2; zob. też: tenże, Roman Kaczmarek, „Dziennik Łódzki” 1995, nr 200, s. 14.

50 Tenże, I. Nagórska, Małgorzata Basińska (1944-1986), „Poradnik Bibliotekarza” 1987, nr 5, s. $18-19$.

${ }^{51}$ Tenże, Jadwiga Siniarska-Czaplicka, „Informator Bibliotekarza i Księgarza na Rok 1988” 1988, s. 253-258.
} 
nane w 1922 roku. Wspomniał więc o: literaturze dziecięcej i adresowanej do młodzieży szkolnej, a więc o tomach słynnej serii Biblioteka Klasyków Polskich Wendego - szesnasto- i siedemnastowiecznych dokumentach, kilkudziesięciu dwudziestowiecznych drukach ulotnych, rękopisach, zbiorze łacińskich epigramatów Johna Owena, cimeliach (np. o francuskim klocku z 1787 roku zawierającym sześć broszurek na temat awantur Cagliostra), dziełach ojca, dziełach Norwida i prawie kompletnej literaturze przedmiotu do badań nad biografią i twórczością tego poety doby romantyzmu ${ }^{52}$.

Biografista zajął się również dziejami rodziny Książków, a dokładniej życiem Stanisława Książka (1860-1928) posługującego się przybranym nazwiskiem Staszewski. Z badań Kempy wynika, że był on dziennikarzem, aktorem teatralnym, właścicielem drukarni i rzekomym pierwszym wydawcą Juliana Tuwima. Badacz prześledził losy Stanisława Książka. Wysnuł wniosek jakoby informacja Adama Ochockiego - autora Reportera przed konfesjonałem, czyli jak się w Łodzi przed wojną robiło gazetę o akceptacji do druku przez rzeczonego Książka debiutu literackiego Tuwima nie była wiarygodna. Poeta debiutował bowiem na łamach prasy, gdy Stanisław Książek nie przebywał już w Łodzi ${ }^{53}$. Do tego zarzutu odniósł się w 246 numerze „Głosu Porannego” autor Reportera..., konstatując, że owszem jest to prawda, ale w redakcji pozostał brat Stanisława - Antoni, który dalej kierował „Nowym Kurierem Codziennym” ${ }^{4}$.

Kempa w swych poszukiwaniach zajmował się również biografią zapomnianych ludzi książki. Przedstawił sylwetkę bibliofila Adama Jacka Prota Lelewela (1790-1884), brata Joachima, znanego bibliologa i księgoznawcy. Autor postanowił przywrócić go pamięci czytelników i miłośników słowa, albowiem znane szerzej były tylko zdawkowe informacje biograficzne z życia Prota, który troszczył się o spuściznę po bracie. Kempa uzupełnił dane o ważne fakty takie jak edukacja, praca zawodowa i parlamentarna oraz o udział w kampanii moskiewskiej. Ponadto omówił jego prace dotyczące wspomnień o bracie Joachimie, wydarzeń $\mathrm{z}$ okresu wojen napoleońskich, biografię wuja - arcybiskupa mohylewskiego Kaspra Cieciszewskiego, metropolity kościołów rzymskokatolickich w cesarstwie rosyjskim ${ }^{55}$.

${ }_{52}$ Tenże, Niestrudzony podróżnik po Szpargalii. W osiemdziesiąta rocznicę urodzin Juliusza Wiktora Gomulickiego, „Poradnik Bibliotekarza” 1989, nr 11-12, s. 30-33.

53 Tenże, Stanisław Książek, „Głos Poranny” 1990, nr 241, s. 8; zob. też: tenże, Stanisław Ksiażek, „Dziennik Łódzki” 1995, nr 119, s. 16.

${ }^{54}$ A. Ochocki, Było dwóch Książków!, „Głos Poranny” 1990, nr 246, s. 3.

55 A. Kempa, Skazany na zapomnienie. W 200 rocznicę urodzin Prota Lelewela, „Bibliotekarz” 1990, nr 10-11, s. 19-[21]. 
Kempa omówił również w krótkim szkicu postać bibliofila Józefa Chudka, właściciela liczącego ponad 10 tysięcy tytułów księgozbioru, bibliotekarza Biblioteki Uniwersytetu Warszawskiego, pracownika naukowego Polskiego Instytutu Spraw Międzynarodowych ${ }^{56}$.

Swoją uwagę bibliolog zwrócił także ku biografii mało znanego bibliofila żyjącego na przełomie XIX i XX wieku - Romualda Ziemkiewicza niesłusznie utożsamianego z Romualdem Zienkiewiczem - badaczem dziejów białoruskiego folkloru. Swe badania opublikował na łamach „Poradnika Bibliotekarza” w cyklu Zapiski bibliofila z książek i z życia wzięte. Autor biografii podał bardzo szczegółowe fakty z życia miłośnika ksiąg, takie jak edukacja czy praca zawodowa, ale skupił się przede wszystkim na jego licznych kradzieżach w warszawskich antykwariatach. Kempa opisał dosyć szeroko skandal zakupu przez dyrektora Biblioteki Narodowej - Stefana Dembego autografu Adama Mickiewicza oraz zakup listu Cypriana Norwida przez Zenona Przesmyckiego-Miriama na aukcji antykwarycznej zorganizowanej dla członków Towarzystwa Bibliofilów w Warszawie. Wydarzenie to odbiło się w środowisku szerokim echem. Sprawcą zamieszania był właśnie Romuald Ziemkiewicz podający się za inżyniera i profesora literatury białoruskiej w Instytucie Wschodnim, który oba teksty wykradł z Biblioteki Krasińskich ${ }^{57}$.

Badacz poświęcił również uwagę znanej łódzkiej bibliotekarce Izabeli Nagórskiej (1913-2001), w latach 1960-1977 kierowniczce Działu Instrukcyjno-Metodycznego Miejskiej Biblioteki Publicznej im. L. Waryńskiego w Łodzi. Wspomniał także o prowadzonych przez nią badaniach nad czytelnictwem grupy zawodowej robotników, a później dzieci i młodzieży w Łodzi. Przypomniał o licznych rozprawach naukowych, artykułach, notach, szkicach i hasłach biograficznych publikowanych na łamach „Bibliotekarza”, „Informatora Bibliotekarza”, „Księgarza”, „Poradnika Bibliotekarza”, „Przeglądu Bibliotecznego" i w Słowniku pracowników książki polskiej. Podkreślił jej ogromną rolę w środowisku bibliotekarskim, wspominając o członkostwie i założycielstwie Łódzkiego Towarzystwa Przyjaciół Książki (1967) ${ }^{58}$.

Biografista przedstawił czytelnikom zmarłego w 2007 roku uczonego Janusza Dunina-Horkowicza (1931-2007). W pośmiertnym wspomnieniu profesora, obok krótkiego omówienia jego najważniejszych prac i przyto-

${ }_{56}$ Tenże, Wszystkiego bibliofilskiego, panie Józefie!, „Bibliotekarz” 1989, nr 7-8, s. 44-45.

57 Tenże, Z bibliofilskiego Pitavala, „Poradnik Bibliotekarza” 1992, nr 10, s. 9-10.

58 Tenże, Izabela Nagórska (1913-2001), „Przegląd Biblioteczny” 2002, nr 1/2, s. [149]-152. Por. tenże, Dorobek naukowy, dydaktyczny i popularyzatorski Izabeli Nagórskiej [w:] Pamięci Izabeli Nagórskiej (1913-2001), pod red. J. Andrzejewskiego, Łódź 2002, s. 76-87. 
czenia kilku faktów takich jak edukacja, kariera zawodowa, praca naukowo-dydaktyczna, nie zabrakło ciekawostek z życia dyrektora Biblioteki Uniwersytetu Łódzkiego w latach 1984-1987. Kempa przypomniał o zamiłowaniu Dunina do książek, które wykazywał już od najmłodszych lat, a także o zgromadzonych kolekcjach literatury dziecięcej, ekslibrisów i małej grafiki, wszelkiego rodzaju druków i czasopism humorystycznych, w tym variach oraz o kolekcjach publikacji dotyczących miasta jego dzieciństwa, a więc Wilna i szeroko pojętych lithuaników i licznych starodruków ${ }^{59}$.

Zajmując się badaniami nad biografistyką bibliotekarzy, bibliofilów i bibliologów, Kempa zwracał również uwagę na ciekawostki z życia ludzi książki i dziejów bibliotek, które zainteresowałaby czytelników. Nawiązał więc do problemu gromadzenia zbiorów przez książnice narodowe. Na łamach "Gazety Kieleckiej” opublikował tekst o bibliotecznych wojażach Samuela Bogumiła Lindego (1771-1847). Linde jako członek Komisji Wyznań Religijnych i Oświecenia Publicznego w Warszawie jeździł po Polsce, szukając książek uzupełniających zbiory powstałego w 1816 roku Uniwersytetu Warszawskiego, albowiem po upadku powstania kościuszkowskiego Rosjanie wywieźli z Warszawy do Petersburga zbiory biblioteki Załuskich. Podczas tych podróży Lindemu udało się zebrać ponad 50 tysięcy książek ${ }^{60}$.

Andrzej Kempa to niewątpliwie ceniony w środowisku bibliolog, który doceniał wartość książki, ale przede wszystkim jej pracowników, a więc twórców słowa i pośredników, czyli wydawców, drukarzy i introligatorów, nakładców, księgarzy i antykwariuszy oraz bibliotekarzy. Zdawał sobie bowiem sprawę z jej doniosłej roli społecznej, dlatego też cenił jej dystrybutorów. Zajmował się biografistyką pracowników tudzież miłośników książki XVIII, XIX, XX i XXI stulecia. Sylwetki ludzi książki prezentował więc w hasłach biograficznych, biogramach, krótkich szkicach, notach i esejach biograficznych oraz przyczynkach do biografii. Niewątpliwie przyświecała mu idea ocalenia ich od zapomnienia albo przywrócenia ich pamięci. W swych badaniach podejmował się niejednokrotnie weryfikacji danych biograficznych jak np. daty czy miejsca urodzenia bądź zamieszkania. Interesował się także problematyką atrybucji dzieł mało znanych pisarzy, dziejami rynku wydawniczego i księgarskiego oraz historią prasy ogólnopolskiej i regionu łódzkiego. Przybliżał czytelnikom postaci mało znanych pisarzy, wydawców i księgarzy. Omawiał edukację, karierę zawodową, pracę nauko-

59 A. Kempa, Janusza Dunina życie wśród ksiąg, „Akapit” 2008, t. 3, s. [151]-153. Por. tenże, Janusz Dunin-Horkowicz: (26.06.1931-27.07.2007), „Bibliotekarz” 2007, nr 10, s. 28-29; tenże, Pamięci przyjaciela: Janusz Dunin-Horkowicz (1931-2007), „Kultura i Biznes” 2007, nr 38, s. 6.

${ }_{60}$ Tenże, Biblioteczne wojaże Lindego, „Gazeta Kielecka” 1994, nr 140, s. 8. 
wą i dydaktyczną oraz twórczość poszczególnych postaci. Zachęcał niejednokrotnie do opracowania dorobku literackiego bądź w postaci monografii, bądź bibliografii. Na łamach specjalistycznej i popularnej prasy o zasięgu ogólnopolskim pisał więc o tych, którzy służyli ludziom stałą, codzienną informacją; o tych, którzy dostarczali czytelnikom strawę duchową; o tych, którzy trudnili się wydawaniem, kolportowaniem i udostępnianiem słowa pisanego. Z tej pasji, która przerodziła się $\mathrm{w}$ wartościowe i wnikliwe badania naukowe, choć nie był etatowym pracownikiem naukowym, zrodziło się blisko sto biogramów ludzi książki.

\begin{abstract}
Andrzej Kempa as a researcher of book people biographies

Andrzej Kempa (1936-2009) is the author of many works on the lovers of words. His research was concentrated on the biograms of book people (journalists, writers, bibliophiles, librarians, bibliologists, publishers, book-sellers, printers, illustrators) published in Encyklopedia wiedzy o książce, Polski słownik biograficzny and Słownik pracowników ksiązki polskiej and small articles published in the pages of local and national press. He presented a little-known writers, publishers and booksellers. He discussed their education, career, research and teaching work. Kempa verified their biographical data (date and place of birth). He also discussed the issues of attributions of little-known writers' works, the history of the publishing and the bookshop market and the history of local press.
\end{abstract}

